\title{
Polityka karna sądów w sprawach o przestępstwa przeciwko rodzinie i opiece w latach 2008-2018
}

\section{Criminal policy of Polish courts in cases of crimes against family and guardianship in 2008-2018}

\begin{abstract}
ABSTRAKT: Artykuł dotyczy polityki karnej sądów w sprawach o przestępstwa przeciwko rodzinie i opiece w latach 2008-2018. W opracowaniu przedstawiono wyniki analizy sądowych danych statystycznych obrazujących tendencje orzecznicze sądów karnych w sprawach o przestępstwa określone w XXVI rozdziale kodeksu karnego. W tekście starano się przede wszystkim odpowiedzieć na pytanie, czy zmiany w prawie karnym, które miały miejsce w 2015 i 2017 r. spośród których jedna miała istotne znaczenie dla całego systemu prawa karnego w Polsce, druga zaś okazała się niezwykle ważka zwłaszcza w kontekście przestępstw godzących w dobro rodziny i opieki - wpłynęły w jakimś zakresie na orzecznictwo skazujące sprawców przestępstw przeciwko rodzinie oraz opiece.
\end{abstract}

SŁOWA KLUCZOWE: przestępczość przeciwko rodzinie i opiece, orzecznictwo, kara ograniczenia wolności, kara pozbawienia wolności

ABSTRACT: The article concerns the criminal policy of courts in cases concerning offenses against the family and guardianship in 2008-2018. The study presents the results of the analysis of statistical data illustrating the judicial tendencies of criminal courts in cases of offenses specified in Chapter XXVI of the Penal Code. The text tries to answer the question: did the changes in criminal law that took place in 2015 and 2017 influenced to some extent the jurisprudence on crime against the family and care? In the article, the amendments from these two years were analyzed with particular attention, as one of them was essential for the entire criminal law system in Poland, while the other was extremely important, especially in the context of crimes harming the welfare of the family and care.

KEYWORDS: crimes against family and guardianship, jurisprudence, restriction of liberty, imprisonment 


\section{Wprowadzenie}

Jedną z podstawowych funkcji prawa karnego jest ochrona pewnych dóbr, których istnienie i respektowanie tworzy porządek w społeczeństwie. Realizacją funkcji ochronnej zajmuje się m.in. sąd rozpoznający sprawę dotyczącą popełnienia określonego przestępstwa, który podczas wyrokowania kieruje się ochronnym efektem represji karnej ${ }^{1}$. Wśród dóbr prawnych, których ochroną zajmuje się prawo karne, są np. życie i zdrowie człowieka, jego wolność i bezpieczeństwo, a także rodzina, powszechnie rozumiana jako podstawowa grupa będąca fundamentem organizacji życia społecznego. O tym, że rodzina jest niezwykle ważnym dobrem wymagającym szczególnej troski i opieki ze strony społeczeństwa, a przede wszystkim państwa, świadczy również rozbudowany katalog aktów prawnych regulujących kwestie związane z jej funkcjonowaniem, a także funkcjonowaniem jednostek do niej przynależnych ${ }^{2}$.

Zasadniczą funkcję w ochronie rodziny na gruncie prawa karnego pełni rozdział XXVI kodeksu karnego ${ }^{3}$, w którym ustawodawca określił katalog przestępstw godzących w dobro rodziny i opieki, zaliczając do tej grupy: bigamię (art. 206 k.k.), znęcanie się (art. 207 k.k.), rozpijanie (art. 208 k.k.), uchylanie się od alimentów (art. 209 k.k.), porzucenie (art. 210 k.k.), porwanie (art. 211 k.k.) oraz organizowanie adopcji wbrew przepisom ustawy (art. 211a k.k.). Należy jednak mieć na uwadze, że ochrona rodziny nie ogranicza się jedynie do stanowienia przepisów, lecz polega również na odpowiednim ich stosowaniu wobec sprawców wymienionych przestępstw.

Działalność sądów mająca na celu przeciwdziałanie i ograniczanie przestępczości w drodze stosowania przepisów prawa karnego to polityka karna, instrumentami tej działalności zaś są podejmowane przez sąd decyzje, które przede wszystkim przybierają formę orzeczeń i zarządzeń ${ }^{4}$. Ze względu na doniosłe znaczenie rodziny w społeczeństwie przedmiotem niniejszego opracowania uczyniono politykę karną procedowaną właśnie w obszarze przestępczości godzącej w dobro rodziny i opieki. Najważniejszym etapem realizacji polityki karnej, tuż po uchwaleniu prawa karnego, jest działalność orzecznicza sądów karnych ${ }^{5}$,

1 L. Gardocki, Prawo karne, Wolters Kluwer, Warszawa 2019, s. 7.

2 Tytułem przykładu wymienić można choćby kodeks rodzinny i opiekuńczy z dnia 25 lutego 1964 r. (t.j. Dz.U. z 2019 r., poz. 2086), ustawę o pomocy społecznej z dnia 12 marca 2004 r. (t.j. Dz.U. z 2019 r., poz. 1507), ustawę o świadczeniach rodzinnych z dnia 28 listopada 2003 r. (t.j. Dz.U. z 2020 r., poz. 111), ustawę o Karcie Dużej Rodziny z dnia 5 grudnia 2014 r. (t.j. Dz.U. z 2019 r., poz. 1390) czy ustawę o pomocy osobom uprawnionym do alimentów z dnia 7 września 2007 r. (t.j. Dz.U. z 2019 r., poz. 670).

3 Ustawa z dnia 6 czerwca 1997 r. - Kodeks karny (t.j. Dz.U. z 2020 r., poz. 1444).

4 J. Błachut, T. Szymanowski, Polityka karna w Polsce współczesnej w świetle przepisów prawa $i$ danych empirycznych, w: System Prawa Karnego. Zagadnienia ogólne, t. 1, red. A. Marek, C.H.Beck, Warszawa 2010, s. 57.

5 Ibidem, s. 72. 
analizie poddano więc dane statystyczne dotyczące orzekanych przez sądy kar w sprawach o przestępstwa określone w XXVI rozdziale kodeksu karnego.

Celem podjęcia tytułowej problematyki było uzupełnienie i zaktualizowanie wiedzy o obrazie przestępczości przeciwko rodzinie i opiece oraz działalności orzeczniczej w latach 2008-2018 zmierzającej do ograniczenia tego zjawiska. W literaturze przedmiotu można znaleźć opracowania dotyczące przestępczości stwierdzonej popełnianej przeciwko rodzinie ${ }^{6}$. Jednak artykuły, rozdziały czy monografie prezentują wybrane zagadnienia przede wszystkim z obszaru etiologii i fenomenologii kryminalnej dotyczącej przestępczości danego rodzaju. Wypada zatem uzupełnić je rozważaniami z obszaru polityki kryminalnej prowadzonej wobec sprawców tytułowej grupy przestępstw, zwłaszcza że jest ona elementem składowym kryminologii stosowanej ${ }^{7}$.

Analizą objęto statystyki sądowe dotyczące prawomocnie skazanych dorosłych ułożone według rodzajów przestępstw i wymiaru kary za czyn główny w latach 2008-2018. Wybór tego dziesięcioletniego przedziału czasowego podyktowany był dostępnością danych sądowych - nowsze, z lat 2019 i 2020, nie zostały do chwili powstania finalnej wersji tekstu jeszcze opublikowane.

\section{Skazania za przestępstwa przeciwko rodzinie i opiece wśród ogółu skazań w Polsce}

Podejmując się analizy problematyki przestępczości przeciwko rodzinie i opiece, należy wskazać, że stwierdzone przestępstwa tego rodzaju nie stanowią dużej części ogólnego obrazu przestępczości w naszym kraju, policja odnotowuje bowiem co roku kilkadziesiąt tysięcy przestępstw tego typu, które rokrocznie odpowiadają za nie więcej niż 5\% przestępczości w Polsce ${ }^{8}$. Sytuacja ta zmienia się jednak nieznacznie, gdy spojrzymy na omawiany rodzaj przestępczości z per-

6 Zob. m.in. B. Gruszczyńska, Przemoc wobec kobiet w Polsce. Aspekty prawnokryminologiczne, Wolters Kluwer, Warszawa 2007, ss. 244; M. Budyn-Kulik, Przemoc w rodzinie - analiza wiktymologiczna oraz prawnokarne środki przeciwdziałania, Instytut Wymiaru Sprawiedliwości, Warszawa 2009, ss. 99; E. Kruk, Przemoc $w$ rodzinie a ofiara i zabezpieczenie jej praw $w$ świetle procedury „Niebieskiej Karty” i cywilnego „nakazu opuszczenia lokalu” ustawy o przeciwdziałaniu przemocy $w$ rodzinie, „Annales Universitatis Mariae Curie-Skłodowska Lublin - Polonia” 2016, vol. 63, nr 1, s. 81-97; D. Dajnowicz-Piesiecka, Przestępczość przeciwko rodzinie i opiece w Polscewybrane aspekty prawnokarne i kryminologiczne, w: Prawo publiczne i prawo karne w XXI wieku. Wybrane zagadnienia, red. Ł.B. Pilarz, Wydawnictwo Naukowe TYGIEL, Lublin 2019, s. 61-72; D. Dajnowicz-Piesiecka, Przestępczość godząca w rodzinę. Studium prawno-kryminologiczne, Temida 2, Białystok 2020, ss. 170.

7 W. Filipkowski, E.M. Guzik-Makaruk, Zagadnienia podstawowe kryminologii jako nauki, w: E.W. Pływaczewski i in., Kryminologia. Stan i perspektywy rozwoju. Z uwzględnieniem założeń Agendy ONZ na rzecz zrównoważonego rozwoju 2030, Wolters Kluwer, Warszawa 2019, s. 28 i n.

8 D. Dajnowicz-Piesiecka, Przestępczość godząca $w$ rodzinę..., s. 129-130. 
spektywy statystyki sądowej, a przede wszystkim danych obrazujących rozmiar skazań. Informacje w tym zakresie przedstawiono w tabeli 1.

TABela 1. Prawomocne skazania za przestępstwa przeciwko rodzinie i opiece w latach 2008-2018

\begin{tabular}{|c|c|c|c|}
\hline Lata & $\begin{array}{l}\text { Prawomocne } \\
\text { skazania } \\
\text { ogółem }\end{array}$ & $\begin{array}{c}\text { Prawomocne skazania } \\
\text { za przestępstwa } \\
\text { przeciwko rodzinie i opiece }\end{array}$ & $\begin{array}{c}\text { Udział skazań } \\
\text { za przestępstwa } \\
\text { przeciwko rodzinie i opiece } \\
\text { wśród skazań ogółem [\%] }\end{array}$ \\
\hline 2008 & 420729 & 25371 & 6 \\
\hline 2009 & 415272 & 26462 & 6 \\
\hline 2010 & 432891 & 31626 & 7 \\
\hline 2011 & 423464 & 29491 & 7 \\
\hline 2012 & 408107 & 24740 & 6 \\
\hline 2013 & 353208 & 25667 & 7 \\
\hline 2014 & 295353 & 24488 & 8 \\
\hline 2015 & 260034 & 21659 & 8 \\
\hline 2016 & 289512 & 20718 & 7 \\
\hline 2017 & 241436 & 17802 & 7 \\
\hline 2018 & 275768 & 53301 & 19 \\
\hline
\end{tabular}

Źródło: Opracowanie własne na podstawie Informatora Statystycznego Wymiaru Sprawiedliwości: https:// www.isws.ms.gov.pl/pl/baza-statystyczna/ [dostęp: 1.12.2020].

Z zaprezentowanych $\mathrm{w}$ tabeli 1 statystyk sądowych wynika, że w latach 2008-2018 liczbę prawomocnych skazań w Polsce cechował trend spadkowy. W przypadku skazań za przestępstwa przeciwko rodzinie i opiece przez większość okresu również obserwowano taką tendencję. Do 2017 r. skazania za te przestępstwa odpowiadały za od $6 \%$ do $8 \%$ wszystkich orzeczonych w Polsce skazań. Trend ten jednak uległ poważnej zmianie w 2018 r., gdy doszło do 53301 skazań za przestępstwa przeciwko rodzinie i opiece. $\mathrm{W}$ tym roku udział skazań za ten rodzaj występków wśród wszystkich skazań w Polsce wzrósł aż do 19\%. Oznacza to, że w 2018 r. niemalże co piąte skazanie następowało w związku z popełnieniem przestępstwa przeciwko rodzinie i opiece.

Warto zastanowić się, co było przyczyną tak wysokiego wzrostu liczby skazań za przestępstwa przeciwko rodzinie i opiece. W literaturze przedmiotu wskazuje się, że jeśli zmiany w przestępczości (w tym przypadku w przestępczości osądzonej wyrokiem skazującym) są raptowne i można je ulokować w konkretnym momencie czasowym, musi istnieć konkretna przyczyna takiego stanu rzeczy ${ }^{9}$. Tak też było $\mathrm{w}$ tym przypadku - zmiana w liczbie skazań była bowiem pokłosiem

\footnotetext{
9 J. Błachut, Problemy związane z pomiarem przestępczości, Lex, Warszawa 2007.
} 
nowelizacji art. 209 k.k., wprowadzonej w 2017 r. ustawą o zmianie ustawy Kodeks karny oraz ustawy o pomocy osobom uprawnionym do alimentów ${ }^{10}$.

Do istotnych zmian wprowadzonych ustawą nowelizującą należało poszerzenie zakresu kryminalizacji zachowań społecznych związanych z wywiązywaniem się z obowiązku alimentacyjnego ${ }^{11}$. Występujące wcześniej w art. 209 k.k. znamiona „uporczywości” uchylania się od realizacji obowiązku opieki i „niemożności zaspokojenia podstawowych potrzeb życiowych" uprawnionego usunięto, zastępując je kryteriami obiektywnymi w postaci zaległości alimentacyjnych stanowiących równowartość co najmniej trzech świadczeń okresowych albo opóźnienia zaległego świadczenia innego niż okresowe wynoszącego minimum 3 miesiące. Zmiany te spowodowały wzrost postępowań wszczętych w związku ze zgłoszeniem popełnienia przestępstwa z art. 209 k.k., wzrost liczby przestępstw stwierdzonych i w końcu wzrost liczby skazań za to przestępstwo. Warto nadmienić, że choć nowelizacja wprowadzona została w 2017 r., to jej oddziaływanie na statystykę sądową widoczne jest dopiero w danych z 2018 r., czas trwania postępowania prowadzącego do skazania sprawcy jest bowiem znacznie bardziej wydłużony w porównaniu np. do czasu, który potrzebują organy ścigania do stwierdzenia przestępstwa.

\section{Tendencje orzecznicze w obszarze przestępczości przeciwko rodzinie i opiece}

Rozpoczynając analizę orzecznictwa sądowego wydanego w sprawach o przestępstwa przeciwko rodzinie i opiece w latach 2008-2018, należy przyjrzeć się ogólnym informacjom liczbowym o rodzajach kar orzeczonych wobec skazanych. Dane w tym zakresie przedstawiono w tabeli 2.

Na podstawie danych liczbowych zawartych w tej tabeli można zauważyć, że $\mathrm{w}$ orzecznictwie dotyczącym przestępczości przeciwko rodzinie i opiece w dziesięcioletnim okresie objętym analizą doszło do dość istotnych zmian, które wyraźnie zarysowują się przede wszystkim w latach 2016-2018.

Od 2008 do 2015 r. wiodącą karą, na którą skazywano za przestępstwa przeciwko rodzinie i opiece, była kara pozbawienia wolności - co roku orzekano ją w ponad $80 \%$ wszystkich skazań za przestępstwa tego rodzaju. Należy przy tym zwrócić uwagę na to, że udział pozbawienia wolności wśród ogółu kar orzekanych za przestępstwa przeciwko rodzinie i opiece zmniejszał się przez lata jeszcze w 2008 r. wynosił 90\%, w 2015 r. zaś kształtował się na poziomie 83\%.

${ }^{10}$ Ustawa z dnia 23 marca 2017 r. o zmianie ustawy - Kodeks karny oraz ustawy o pomocy osobom uprawnionym do alimentów (Dz.U. z 2017 r., poz. 952).

${ }^{11}$ A. Rusin-Batko, Nowy model normatywny przestępstwa niealimentacji jako reakcja ustawodawcy na przejaw patologii społecznej, w: Istota, faktyczność i legitymizacja prawa karnego, red. J. Piskorski, C.H.Beck, Warszawa 2019, s. 84. 
TABELA 2. Rodzaje kar orzekanych za przestępstwa przeciwko rodzinie i opiece w latach 20082018

\begin{tabular}{|c|c|c|c|c|c|c|c|c|c|c|c|c|}
\hline \multirow[t]{2}{*}{ Lata } & \multicolumn{2}{|c|}{$\begin{array}{l}\text { Prawomocne } \\
\text { skazania } \\
\text { za przestępstwa } \\
\text { przeciwko } \\
\text { rodzinie i opiece }\end{array}$} & \multicolumn{2}{|c|}{$\begin{array}{c}\text { Kara } \\
\text { grzywny } \\
\text { samoistnej }\end{array}$} & \multicolumn{2}{|c|}{$\begin{array}{c}\text { Kara } \\
\text { ograniczenia } \\
\text { wolności }\end{array}$} & \multicolumn{2}{|c|}{$\begin{array}{c}\text { Kara } \\
\text { pozbawienia } \\
\text { wolności }\end{array}$} & \multicolumn{2}{|c|}{$\begin{array}{c}\text { Kara } \\
\text { grzywny } \\
\text { orzeczona } \\
\text { obok kary } \\
\text { pozbawienia } \\
\text { wolności }\end{array}$} & \multicolumn{2}{|c|}{$\begin{array}{c}\text { Kara } \\
\text { mieszana }\end{array}$} \\
\hline & l.b. & [\%] & l.b. & [\%] & 1.b. & [\%] & l.b. & [\%] & 1.b. & [\%] & l.b. & [\%] \\
\hline 2008 & 25371 & 100 & 414 & 2 & 2077 & 8 & 22858 & 90 & 1161 & 5 & & \\
\hline 2009 & 26462 & 100 & 374 & 1 & 2455 & 9 & 23618 & 89 & 1189 & 4 & & \\
\hline 2010 & 31626 & 100 & 392 & 1 & 3779 & 12 & 27454 & 87 & 1120 & 4 & & \\
\hline 2011 & 29491 & 100 & 328 & 1 & 3277 & 11 & 25885 & 88 & 994 & 3 & & \\
\hline 2012 & 24740 & 100 & 304 & 1 & 2560 & 10 & 21873 & 88 & 909 & 4 & & \\
\hline 2013 & 25667 & 100 & 320 & 1 & 3071 & 12 & 22276 & 87 & 799 & 3 & & \\
\hline 2014 & 24488 & 100 & 334 & 1 & 3230 & 13 & 20924 & 85 & 788 & 3 & & \\
\hline 2015 & 21659 & 100 & 362 & 2 & 3300 & 15 & 17950 & 83 & 726 & 3 & 47 & 0,2 \\
\hline 2016 & 20718 & 100 & 874 & 4 & 6389 & 31 & 13190 & 64 & 527 & 3 & 264 & 1 \\
\hline 2017 & 17802 & 100 & 838 & 5 & 6132 & 34 & 10580 & 59 & 366 & 2 & 252 & 1 \\
\hline 2018 & 53301 & 100 & 3863 & 7 & 31047 & 58 & 18042 & 34 & 460 & 1 & 349 & 1 \\
\hline
\end{tabular}

Źródło: Opracowanie własne na podstawie Informatora Statystycznego Wymiaru Sprawiedliwości: https:// www.isws.ms.gov.pl/pl/baza-statystyczna/ [dostęp: 1.12.2020].

W kolejnych latach zmniejszył się jeszcze bardziej, albowiem w 2016 r. kary pozbawienia wolności orzeczono w przypadku $64 \%$ skazań za przestępstwa godzące w dobro rodziny, w 2017 r. 59\% skazań zawierało taką karę, z kolei w 2018 r. już tylko w co trzecim przypadku orzekano karę pozbawienia wolności (34\%).

W latach 2008-2015 w znacznie mniejszym zakresie sądy orzekały karę ograniczenia wolności. Jej udział w orzeczeniach skazujących za przestępstwa przeciwko rodzinie i opiece kształtował się w tamtym czasie na poziomie od $8 \%$ w 2008 do 15\% w 2015 r. Jednak z roku na rok rola tej kary w orzeczeniach skazujących za przedmiotowe przestępstwa rosła. Duże zmiany zaczęły następować od 2016 r., w kolejnych latach zaś pogłębiały się. W 2016 r. udział skazań na karę ograniczenia wolności w porównaniu z 2015 r. zwiększył się do 31\%, czyli aż o 16 punktów procentowych. W kolejnym, 2017 r. ponownie odnotowano wzrost tym razem udział tej kary w skazaniach wyniósł $34 \%$. Jednak największy wzrost odnotowano w ostatnim roku objętym analizą - wówczas odsetek skazań na ograniczenie wolności powiększył się do 58\%. Tym samym należy stwierdzić, że w 2018 r. głównym instrumentem sądowej reakcji na przestępstwa przeciwko rodzinie i opiece była kara ograniczenia wolności. 
Warto również odnotować, że w orzecznictwie dotyczącym przestępstw przeciwko rodzinie i opiece wzrosła nieco rola kary grzywny samoistnej, co jest widoczne zwłaszcza w latach 2016, 2017 i 2018 - wówczas udział tej kary pośród wszystkich skazań za przestępstwa godzące w dobro rodziny kształtował się na poziomie $4-7 \%$, podczas gdy w latach wcześniejszych kary te orzekano w przypadku zaledwie ok. 1\% skazań.

Należy jeszcze zwrócić uwagę na karę mieszaną, w przedmiocie której wartości liczbowe przedstawiono tylko z lat 2015-2018 - wprowadzono ją bowiem dopiero w 2015 r. ${ }^{12}$. Zgodnie z art. 37b k.k., określającym zasady wymierzania tej kary, w sprawie o występek zagrożony karą pozbawienia wolności, niezależnie od dolnej granicy ustawowego zagrożenia przewidzianego w ustawie za dany czyn, sąd może orzec jednocześnie karę pozbawienia wolności w wymiarze nieprzekraczającym 3 miesięcy, jeżeli górna granica ustawowego zagrożenia wynosi przynajmniej 10 lat - 6 miesięcy, oraz karę ograniczenia wolności do lat 2 . Głównym celem wprowadzenia do polskiego kodeksu karnego kary mieszanej było uelastycznienie wymiaru kary za występki w ten sposób, by sąd przy wyborze sankcji nie ograniczał się jedynie do kary pozbawienia wolności ${ }^{13}$.

Od chwili wejścia w życie reformy z 2015 r. sądy orzekające w sprawach o przestępstwa przeciwko rodzinie i opiece niemalże od razu zaczęły sięgać po karę mieszaną. Choć z danych statystycznych zawartych w tabeli 2 wynika, że sankcja ta nie miała dużego udziału pośród skazań za przestępstwa omawianego rodzaju, patrząc na ogólną częstotliwość sięgania przez wymiar sprawiedliwości po karę mieszaną, to w przypadku przestępstw przeciwko rodzinie i tak korzystano z tego instrumentu dość często. Zgodnie bowiem ze statystykami wymiaru sprawiedliwości w 2015 r. w sumie orzeczono w Polsce 370 kar mieszanych, z czego 47 (13\%) wobec sprawców przestępstw przeciwko rodzinie i opiece (a przede wszystkim sprawców znęcania się i uchylania się od obowiązku alimentacyjnego). W kolejnych latach udział ten kształtował się już na nieco niższym poziomie (co roku ok. 10\%), niemniej jednak warte odnotowania jest, że sankcja ta - choć w niewielkim zakresie - została wykorzystana przez sądy orzekające w sprawach o przestępstwa godzące w rodzinę.

$\mathrm{Na}$ tej podstawie należy stwierdzić, że orzecznictwo dotyczące przestępstw przeciwko rodzinie i opiece zmieniło się w ostatnich latach w sposób dość istotny, ponieważ w obszarze skazań nastąpił wyraźny zwrot ku karom nieizolacyjnym. W dużej mierze jest to pokłosie reformy prawa karnego z 2015 r., której głównym celem było zwiększenie w strategii polityczno-kryminalnej roli kary grzywny i kary ograniczenia wolności.

12 Ustawa z dnia 20 lutego 2015 r. o zmianie ustawy - Kodeks karny oraz niektórych innych ustaw (Dz.U. z 2015 r., poz. 396).

${ }_{13}$ A. Grześkowiak, Komentarz do art. $37 b$ k.k., w: Kodeks karny. Komentarz, red. A. Grześkowiak, K. Wiak, Legalis, Warszawa 2021. 


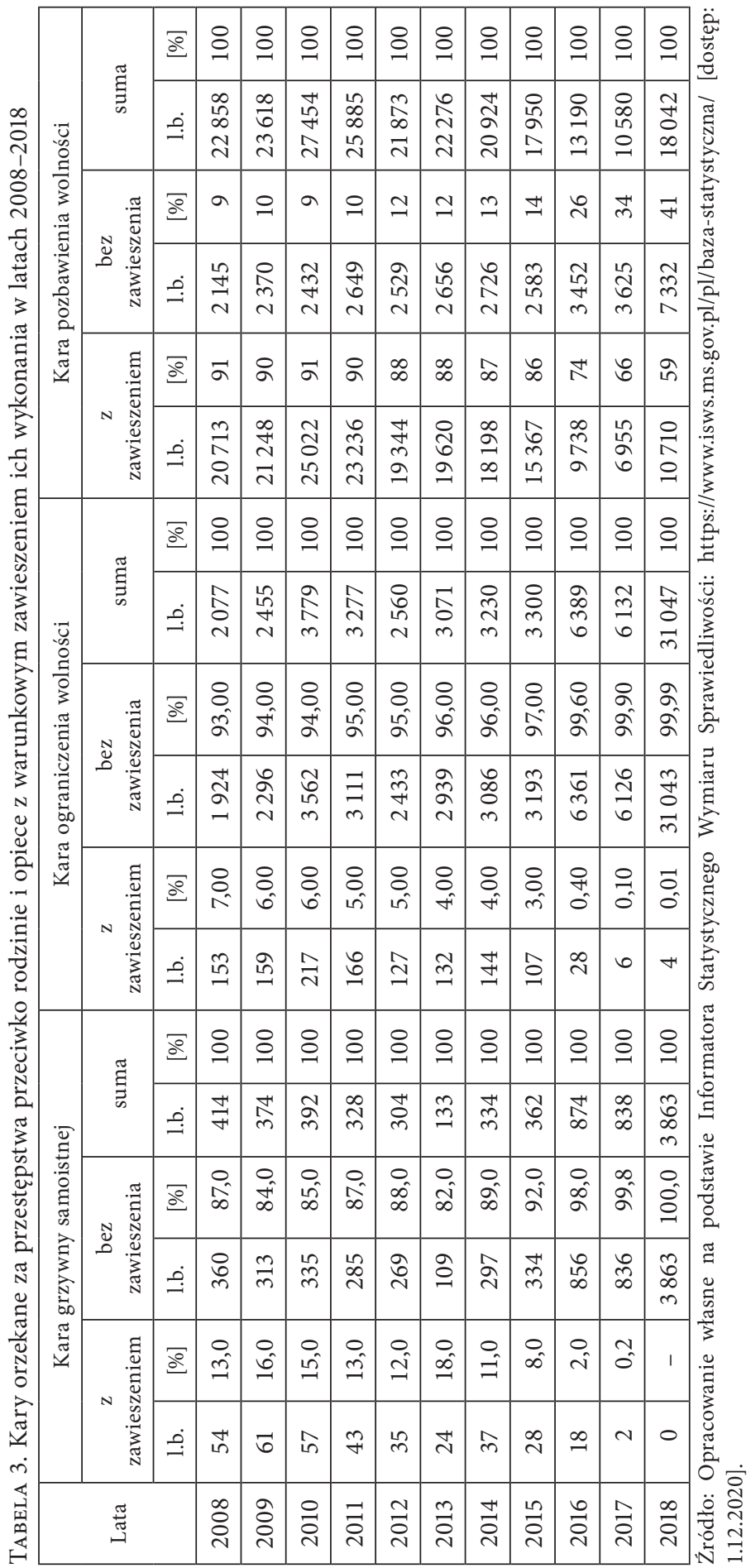


Projektodawcy reformy podnosili, że jest ona potrzebna ze względu na nadużywanie w orzecznictwie sądów karnych kary pozbawienia wolności, zwłaszcza orzekanej z warunkowym zawieszeniem jej wykonania, stanowiła ona bowiem do 2014 r. ponad 60\% konkluzji procesowych, przybierając najczęściej postać „czystej probacji, czyli wyłącznie zagrożenia, że w przypadku kolejnego naruszenia porządku prawnego (oczywiście w zależności od stopnia tego naruszenia) nastąpi zarządzenie wykonania kary pozbawienia wolności”14. W tym miejscu warto zatem przyjrzeć się zmianom w zakresie orzekania kar kryminalnych $\mathrm{z}$ warunkowym zawieszeniem ich wykonania. Informacje na ten temat przedstawiono w tabeli 3.

Z danych liczbowych prezentowanych w tej tabeli wynika, że do 2015 r. główną rolę w orzecznictwie w sprawach o przestępstwa przeciwko rodzinie i opiece odgrywała kara pozbawienia wolności z warunkowym zawieszeniem jej wykonania - niemalże co roku w okresie 2008-2015 90\% skazań na pozbawienie wolności przewidywało jej warunkowo zawieszoną postać. Natomiast w latach 2016, 2017 i 2018 wśród orzeczonych kar pozbawienia wolności udział warunkowo zawieszonych był mniejszy niż we wcześniejszym okresie, jednak odnotować trzeba, że wzrósł wówczas odsetek skazań na pozbawienie wolności bez zawieszenia. Podczas gdy do 2015 r. bezwzględne pozbawienie wolności stanowiło ok. 10\% skazań na ten rodzaj kary, w 2016 r. jego udział wzrósł do 26\%, w 2017 do 34\%, w 2018 r. zaś aż 41\% kar pozbawienia wolności orzeczono w bezwzględnej postaci. Dodatkowo, na podstawie statystyk z tabeli 3 można również stwierdzić, że kary ograniczenia wolności oraz kary grzywny, na które skazywano sprawców przestępstw przeciwko rodzinie i opiece, orzekane były bez warunkowego zawieszania ich wykonania.

\section{Podsumowanie}

$\mathrm{Na}$ podstawie przeanalizowanych danych można wskazać, że praktyka orzecznicza dotycząca przestępstw przeciwko rodzinie i opiece w okresie objętym analizą dość istotnie się zmieniła. Zmiany te są szczególnie dostrzegalne po 2015 r. - wówczas praktyka sądowa ukierunkowała się dwutorowo. Z jednej strony po reformie prawa karnego z 2015 r. na znaczeniu straciła kara pozbawienia wolności z warunkowym zawieszeniem jej wykonania. Jednocześnie jednak, wbrew ogólnym oczekiwaniom, również w przypadku przestępstw przeciwko rodzinie i opiece wzrosła rola kary bezwzględnego pozbawienia wolności ${ }^{15}$. Sądy

14 Uzasadnienie rządowego projektu ustawy o zmianie ustawy - Kodeks karny oraz niektórych innych ustaw, druk nr 2393, http://www.sejm.gov.pl/Sejm7.nsf/druk.xsp?nr=2393 [dostęp: 1.12.2020].

15 Takie tendencje orzecznicze prognozowane były już kilka lat temu m.in. w: M. Melezini, Polityka karna sądów w kontekście reformy prawa karnego, „Nowa Kodyfikacja Prawa Karnego” 2017, nr 43, s. 439. 
orzekają ją głównie w odniesieniu do dwóch przestępstw z rozdziału XXVI kodeksu karnego, a mianowicie skazują na tę karę sprawców fizycznego lub psychicznego znęcania się nad osobą najbliższą lub nieporadną (art. 207 k.k.) bądź osoby uchylające się od obowiązku alimentacyjnego (art. 209 k.k.).

$\mathrm{Z}$ drugiej strony $\mathrm{w}$ ostatnich latach analizowanego okresu na znaczeniu zyskała kara ograniczenia wolności. Liczba skazań na tę karę wzrosła znacząco - jeszcze w 2008 r. była ona bowiem orzekana rzadziej niż w co dziesiątym przypadku skazania za któreś z przestępstw przeciwko rodzinie i opiece, w 2018 r. zaś orzekano ją w więcej niż połowie przypadków. Należy jednak przypomnieć, że w międzyczasie nie tylko wprowadzono poważną reformę prawa karnego, ale istotnie znowelizowano jedno z przestępstw składających się na katalog występków przeciwko rodzinie i opiece. Zmiana, o której mowa, dotyczyła przestępstwa określonego w art. 209 k.k. i to ona przyczyniła się do tego, że wzrosła znacząco liczba skazań za zachowania godzące w dobro rodziny i opieki. Co więcej, głównym instrumentem reakcji wobec sprawców przestępstwa określonego w art. 209 k.k. stała się właśnie kara ograniczenia wolności, co w połączeniu ze zmianami w prawie wyjaśnia tak pokaźny wzrost liczby sytuacji, w których sądy sięgają po ten rodzaj sankcji w przypadku omawianego rodzaju przestępstw.

Wszystko to przekonuje, że polityka karania za przestępstwa przeciwko rodzinie i opiece zmieniła się w ostatnich latach, jednak nie wynika to ze zmiany postaw sędziów czy prokuratorów, lecz przede wszystkim z nowelizacji prawa karnego oraz przeobrażania się rozmiarów tego rodzaju przestępczości. Należy zwrócić uwagę, że przedkładane opracowanie odnosi się do polityki karnej jedynie w zakresie kar kryminalnych, poza rozważaniami zaś pozostawiono analizę środków karnych orzekanych wobec sprawców przestępstw godzących w rodzinę. Publikację tę traktować więc należy jako zaledwie punkt wyjścia do dalszych rozważań dotyczących polityki karnej sądów w sprawach o przestępstwa przeciwko rodzinie i opiece w latach 2008-2018.

\section{Bibliografia}

Błachut J., Problemy związane z pomiarem przestępczości, Lex, Warszawa 2007.

Błachut J., Szymanowski T., Polityka karna w Polsce współczesnej w świetle przepisów prawa i danych empirycznych, w: System Prawa Karnego. Zagadnienia ogólne, t. 1, red. A. Marek, C.H.Beck, Warszawa 2010, s. 53-99.

Budyn-Kulik M., Przemoc w rodzinie - analiza wiktymologiczna oraz prawnokarne środki przeciwdziałania, Instytut Wymiaru Sprawiedliwości, Warszawa 2009.

Dajnowicz-Piesiecka D., Przestępczość godząca w rodzinę. Studium prawno-kryminologiczne, Temida 2, Białystok 2020.

Dajnowicz-Piesiecka D., Przestępczość przeciwko rodzinie i opiece w Polsce - wybrane aspekty prawnokarne $i$ kryminologiczne, w: Prawo publiczne $i$ prawo karne 
w XXI wieku. Wybrane zagadnienia, red. Ł.B. Pilarz, Wydawnictwo Naukowe TYGIEL, Lublin 2019, s. 61-72.

Filipkowski W., Guzik-Makaruk E.M., Zagadnienia podstawowe kryminologii jako nauki, w: E.W. Pływaczewski i in., Kryminologia. Stan i perspektywy rozwoju. Z uwzględnieniem założeń Agendy ONZ na rzecz zrównoważonego rozwoju 2030, Wolters Kluwer, Warszawa 2019, s. 21-65.

Gardocki L., Prawo karne, Wolters Kluwer, Warszawa 2019.

Gruszczyńska B., Przemoc wobec kobiet w Polsce. Aspekty prawnokryminologiczne, Wolters Kluwer, Warszawa 2007.

Grześkowiak A., Komentarz do art. 37b k.k., w: Kodeks karny. Komentarz, red. A. Grześkowiak, K. Wiak, Legalis, Warszawa 2021.

https://www.isws.ms.gov.pl/pl/baza-statystyczna/ [dostęp: 1.12.2020].

Kruk E., Przemoc w rodzinie a ofiara i zabezpieczenie jej praw $w$ świetle procedury „Niebieskiej Karty” i cywilnego „nakazu opuszczenia lokalu” ustawy o przeciwdziałaniu przemocy w rodzinie, „Annales Universitatis Mariae Curie-Skłodowska Lublin - Polonia” 2016, vol. 63, nr 1, s. 81-97.

Melezini M., Polityka karna sąów w kontekście reformy prawa karnego, „Nowa Kodyfikacja Prawa Karnego" 2017, nr 43, s. 421-440.

Rusin-Batko A., Nowy model normatywny przestępstwa niealimentacji jako reakcja ustawodawcy na przejaw patologii społecznej, w: Istota, faktyczność i legitymizacja prawa karnego, red. J. Piskorski, C.H.Beck, Warszawa 2019, s. 77-86.

Uzasadnienie rządowego projektu ustawy o zmianie ustawy - Kodeks karny oraz niektórych innych ustaw, druk nr 2393, http://www.sejm.gov.pl/Sejm7.nsf/druk. $\mathrm{xsp}$ ?nr=2393 [dostęp: 1.12.2020].

\section{dr DIANA DAJNOWICZ-PIESIECKA}

e-mail: d.dajnowicz-piesiecka@uwb.edu.pl

Doktor nauk prawnych, adiunkt w Katedrze Prawa Karnego i Kryminologii na Wydziale Prawa Uniwersytetu w Białymstoku. Autorka szeregu publikacji z zakresu kryminologii i prawa karnego, organizatorka konferencji naukowych, ekspertka w Ministerstwie Nauki i Szkolnictwa Wyższego.

$\mathrm{PhD}$ in law, assistant professor at the Department of Criminal Law and Criminology at the Faculty of Law of the University of Białystok. Author of a number of publications in the field of criminology and criminal law, organizer of scientific conferences, expert at the Ministry of Science and Higher Education. 